\title{
STUDY OF THE KINEMATICS OF A SPADING MACHINE BY USING ENGINEERING SOFTWARE
}

\author{
Nedelcho Delchev ${ }^{1}$, Krasimir Trendafilov ${ }^{2}$ \& Yordan Stoyanov ${ }^{3}$ \\ ${ }^{1}$ Department of Agricultural Engineering, Faculty of Agriculture, Trakia University, Bulgaria \\ 6000 Stara Zagora, Bulgaria, e-mail: ndelchev@abv.bg \\ ${ }^{2}$ Department of Mechanical Engineering, Faculty of Techniques and Technologies, \\ Trakia University, Bulgaria \\ 38 Graf Ignatiev Str., 8600 Yambol, Bulgaria, e-mail: trendafdilov@outlook.com \\ ${ }^{3}$ Department of Agricultural Engineering, Faculty of Agriculture, Trakia University, Bulgaria \\ 6000 Stara Zagora, Bulgaria, e-mail: yordan.stoyanov.stoyanov@gmail.com
}

\begin{abstract}
The article uses the SAM software product to synthesize the kinematic model of a spading machine. Dimensions of the kinematic units are set according to the dimensions of the units of real machines. The trajectory of motion of the working body upon which the size and shape of the soil chips depend is analyzed. The variation in the absolute velocity of the working body in the course of one working cycle is shown. It has been found that when the crankshaft of the spading machine rotates within the range of $90^{\circ}$ and $135^{\circ}$, the velocity of the working body reaches maximum value.

Keywords: spading machine, kinematic model, engineering software, absolute velocity.
\end{abstract}

\section{INTRODUCTION}

The mechanical tillage of soil creates suitable conditions for growing various crop plants. Tillage itself is regarded as a deformation process by interaction of the machine working bodies with the soil itself [11]. Depending on the objectives pursued, the following types of mechanical tillage exist: primary, surface and special [12]. Primary soil tillage means depth cultivation which substantially alters its structure [3].

In our country primary soil tillage is done mainly by turning the surface layer at a depth of about $30 \mathrm{~cm}$ and is practically used in growing all filed crops requiring such tillage. For this purpose, mainly ploughshares are used and the operation is carried out after harvesting the previous crop, that is, during the summer-autumn season. Surface treatments preceding sowing are carried out during the spring season.

In growing vegetable crops outdoors or in greenhouses intensive methods are used and the time between primary tillage and sowing or transplanting is minimal. In these cases it is preferable to carry out the primary tillage with machines with active working organs to provide a grain-size soil composition suitable for the subsequent operations. The primary tillage with them can be done at elevated soil moisture without distorting the microrelief, which is important if watering is by gravitation. According to Coleman [1], primary tillage machines with active working organs are suitable for organic farming and according to their working principle, they are: with rotary working organs (rotary ploughs) and with reciprocating movement (spading machines). Spading machines virtually imitate manual turning of the soil by using a soil with a spade.

The working bodies of spading machines (spades) perform complex motion. The spades move along the frame of the machine, and the machine itself moves along the field. The absolute velocity of the working bodies is the vector sum of the relative and the transmission velocity [9]. There are studies on the kinematics of spading machines to find dependencies to 


\section{ARTTIE $Y$}

Ipplied Resseirlores in Technics, Technologies and Educration

Journal of the Faculty of Technics and Technologies, Trakia University https://sites.google.com/a/trakia-uni.bg/artte/

determine the dimensions of the spading machine units to obtain optimal trajectory of the working bodies $[2,5,6]$.

When comparing the metal consumption and energy consumption of 7 rotary ploughs and 4 spading machines it has been found out that metal consumption was $6-22 \%$ and energy consumption was $9-51 \%$ lower for the rotary ploughs [7]. This is an indirect evaluation and confirmation of the complexity of the kinematics and the structure of spading machines. When testing a Selvatici spading machine model $3012 \mathrm{G}$ digging machine at three working velocities it has been found out that only with this treatment at a depth of $21-23 \mathrm{~cm}$ soil structure suitable for sowing and transplanting on moistened clay soils is achieved. Fuel consumption was $34.1-44.8 \mathrm{~kg} / \mathrm{ha}$, respectively [10].

According to some authors [4], the greatest advantage of using spading machines is that one treatment achieves optimal soil preparation for sowing and planting, which is of paramount importance to vegetable growing and floriculture where production cycles are short and they are several in a year.

The objective of the present paper is to study the kinematics of a spading machine by kinematic model created by a specialized engineering software.

\section{MATERIAL AND METHODS}

The synthesis of kinematic models of the spading machine has been done by the software product SAM [8]. The software product allows drawing of a mechanism, setting operating parameters of that mechanism, and outputting velocity and acceleration graphs relative to the path of selected points of the mechanism.

The following unit dimensions were used to draw the mechanism of the spading machine (Figure 1):

- $\quad$ knee length 13 (crankshaft rotation radius) - $0.15 \mathrm{~m}$;

- $\quad$ arm length for mounting the working body 2+6+7 - $0.35 \mathrm{~m}$;

- length of working body 3 (spade) - $0.26 \mathrm{~m}$;

- distances between the crankshaft axis and the hinge for mounting the timing bar on the frame 5+16 - $0.35 \mathrm{~m}$;

- length of the timing bar $1-0.28 \mathrm{~m}$.

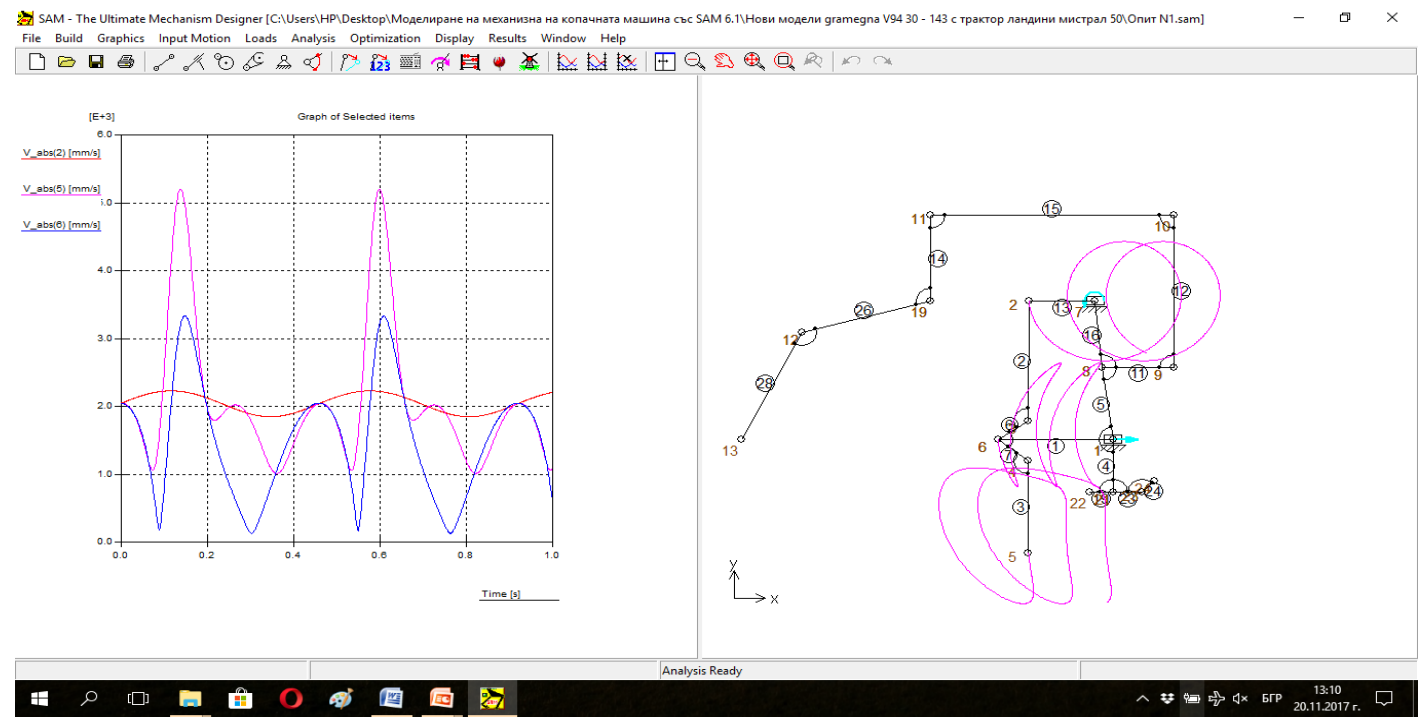

Figure 1. Using the software product SAM for synthesizing a kinematic model of a spading machine

IRTIIE Vol. 5, No. 4, 2017 ISSN 1314-8788 (print), ISSN 1314-8796 (online), doi: 10.15547/artte.2017.04.001 


\section{ART'TE $Y$}

Ipplied Resseirlohes in Technics, Technologies and Eductition

Journal of the Faculty of Technics and Technologies, Trakia University https://sites.google.com/a/trakia-uni.bg/artte/

It is assumed that the tractor with which the machine is aggregated moves in one gear and the changing of engine rotations variations the velocity of movement (working velocity $V_{w}$ ) which takes the following values $0.19 \mathrm{~m} / \mathrm{s}, 0.206 \mathrm{~m} / \mathrm{s}, 0.223 \mathrm{~m} / \mathrm{s}$. Since the velocity of rotation of the independent power take-off shaft (PTOS) of the tractor is proportional to its velocity (within one gear), at the relevant velocities of movement the velocity of rotation of PTOS is $460 \mathrm{~min}^{-1}, 500 \mathrm{~min}^{-1}$ and $540 \mathrm{~min}^{-1}$. The gear ratio of the spading machine reductor is 3.55, therefore the crankshaft velocity of rotation of the machine ranges from $130 \mathrm{~min}^{-1}$ to $152 \mathrm{~min}^{1}$. The rotating crankshaft will drive the work bodies at velocity $V_{l}$. When the machine is in operation, the absolute velocity of the working body $V$ will be:

$$
\vec{V}=\overrightarrow{V_{P}}+\overrightarrow{V_{l}}
$$

The trajectories of movement of selected points in the machine mechanism have been built, the absolute velocity of the working body and the parameters of the soil chips at operation of the spading machine have been determined.

\section{RESULTS AND DISCUSSION}

Figure 2 presents a diagram of a spading machine created by using the software product SAM. The trajectories of point $B$ at the crank of crankshaft 1 of the machine and point $M$ of the working body (spade) 3 of the machine are shown. The trajectory of point B is divided into sections at $45^{\circ}$ by the crankshaft rotation angle. The trajectory of point $\mathrm{M}$ is also divided into sections that correspond to the given rotation angle of the machine crankshaft. It can be seen that the individual sections of the trajectory of point $\mathrm{M}$, corresponding to the same angle $\left(45^{\circ}\right)$ of rotation of the machine crankshaft, are of different length. Accordingly, the absolute velocity at point $M$ of the working body has different meanings at different rotation angle of the machine crankshaft.

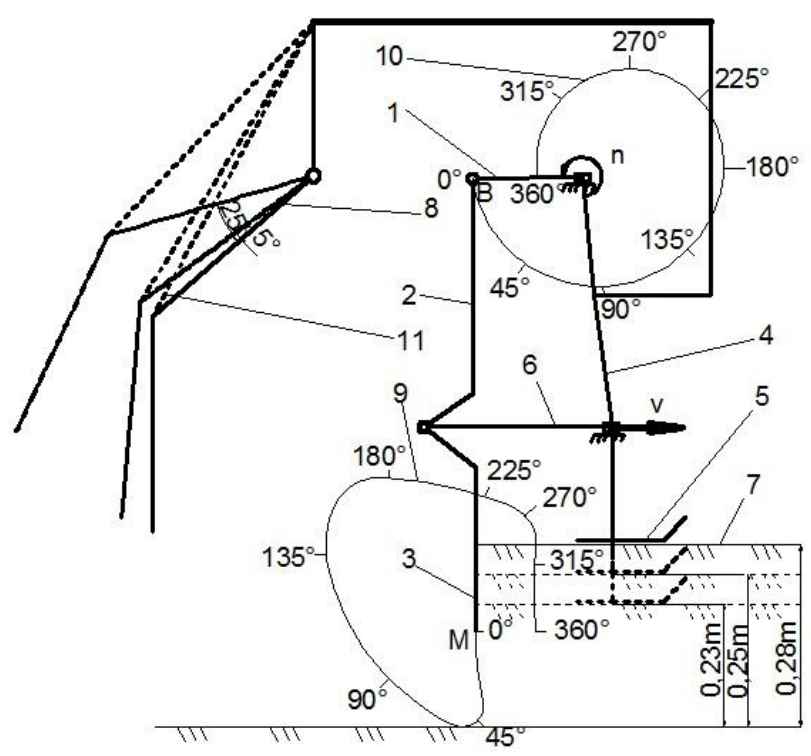

Figure 2. Diagram of a spading machine:

1 - crankshaft; 2 - arm; 3 - working body (shovel); 4 - arm; 5 - sliders; 6 - timing bar; 7 soil layer; 8 - deflector cap; 9 - trajectory of movement of point $\mathrm{M}$ of the working body (the shovel); 10 - trajectory of movement of point B of the crankshaft; 11 - chain for cap adjustment chain

IRTIIE Vol. 5, No. 4, 2017 ISSN 1314-8788 (print), ISSN 1314-8796 (online), doi: 10.15547/artte.2017.04.001 


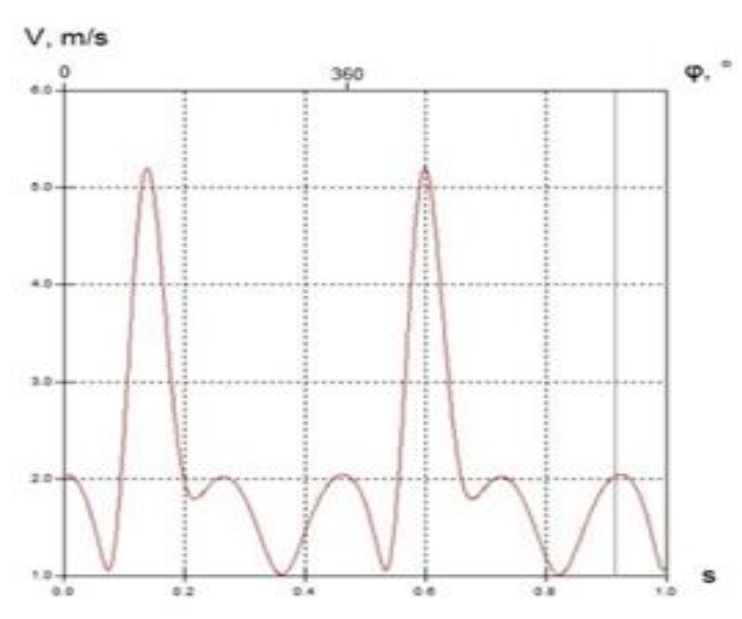

Figure 3. Diagrams for absolute velocity $\mathrm{V}$ at point $\mathrm{M}$ in the mechanism of the spading machine according to the angle $\varphi$ of rotation of the machine crankshaft

Figure 3 is a graphical representation of the variation of the absolute velocity of the $M$ (lower end of the working body) relative to the crankshaft rotation angle. It can be seen that within a small interval of rotation of the machine crankshaft the velocity of point $M$ increases significantly. In this interval the soil is overthrown by the working body, and therefore higher velocity, respectively greater kinetic energy of the overthrown layer is needed in order to obtain better fragmentation of the soil.

The values of the trajectory and the absolute velocity of point $M$ of the working body of the machine are shown in table 1 . It shows that the total length of the road traversed by point $M$ of the working body of the machine does not change and is about $1 \mathrm{~m}$ per revolution of the crankshaft. The absolute velocity of the working body increases with an increase in PTOS rotation frequency from $5,203 \mathrm{~m} / \mathrm{s}$ at $460 \mathrm{~min}^{-1}$ to $6,165 \mathrm{~m} / \mathrm{s}$ at $540 \mathrm{~min}^{-1}$. The absolute velocity of the working body reaches its maximum in the range between $90^{\circ}$ and $135^{\circ}$ of the crankshaft rotation.

The trajectory covered by point $M$ on the spade on the vertical plain OXY (Figure 4) can be divided depending on the process carried out by the spade into the following sections:

- $A-B$ - inserting the spade into the soil;

- $\quad B-C-$ overthrowing the soil;

- $\quad$ C - D - moving the spade for the next insertion.

The Soil chip is the area surrounded by points ADOB. It can be seen that it has almost

Rectangular cross section (Figure $5 b$ ). The thickness of the chip is equal to the distance between points $A$ and $D$, which is the step of the working body. In individual sections, the absolute velocity value changes as follows: when the spade penetrates into the soil it is the lowest; when the soil aggregates are dropped off the spade, the speed reaches its maximum; when shifting the spade for subsequent penetration into the soil, the speed is slightly higher than that at insertion.

Figure 4 shows the step of the working body of the spading machine - the distance between two identical points of two consecutive trajectories. At the accepted operating parameters it is $0.088 \mathrm{~m}$. The step of the machine is determined analytically by the expression

$$
X=\frac{60 . V_{p} . i}{n}, \quad m
$$


where $V_{w}$ is the progressive speed of the machine, $\mathrm{m} / \mathrm{s}$;

$i$ - the transmission ratio of the reductor of the spading machine;

$n$ - rotation speed of the tractor power take-off shaft, $\mathrm{min}^{-1}$

The rotation speed $n$ of the tractor PTOS at the same tractor gear changes in pro rata to the crankshaft rotation frequency of the tractor engine, and the speed of movement $V_{w}$ also changes accordingly. For this reason, the machine step remains constant when changing the rotation frequency of the PTOS within the gear used.

Table 1. Values of absolute velocities and the distance covered by point $M$ of the spade depending on the crankshaft rotation angle of the machine

\begin{tabular}{|c|c|c|}
\hline Crankshaft rotation angle, ${ }^{\circ}$ & Distance covered by point $\mathrm{M}, \mathrm{m}$ & Absolute velocity $\mathrm{V}, \mathrm{m} / \mathrm{s}$ \\
\hline \multicolumn{3}{|c|}{ At rotation frequency of PTOS $n=460 \mathrm{~min}^{-1}$} \\
\hline 45 & 0.104 & 1.3 \\
\hline 90 & 0.215 & 4.05 \\
\hline 135 & 0.482 & 3.29 \\
\hline 180 & 0.607 & 1.862 \\
\hline 225 & 0.721 & 1.91 \\
\hline 270 & 0.808 & 1.09 \\
\hline 315 & 0.876 & 1.53 \\
\hline 360 & 0.985 & 2.04 \\
\hline \multicolumn{2}{|r|}{ Max } & 5.203 \\
\hline \multicolumn{2}{|r|}{ Min } & 1.009 \\
\hline \multicolumn{3}{|c|}{ At rotation frequency of PTOS $n=500 \mathrm{~min}^{-1}$} \\
\hline 45 & 0.103 & 1.48 \\
\hline 90 & 0.213 & 4.33 \\
\hline 135 & 0.484 & 3.69 \\
\hline 180 & 0.61 & 2 \\
\hline 225 & 0.722 & 2.097 \\
\hline 270 & 0.812 & 1.22 \\
\hline 315 & 0.879 & 1.61 \\
\hline 360 & 0.997 & 2.22 \\
\hline \multicolumn{2}{|r|}{ Max } & 5.72 \\
\hline \multicolumn{2}{|r|}{ Min } & 1.136 \\
\hline \multicolumn{3}{|c|}{ At rotation frequency of PTOS $\mathrm{n}=540 \mathrm{~min}^{-1}$} \\
\hline 45 & 0.104 & 1.57 \\
\hline 90 & 0.214 & 4.73 \\
\hline 135 & 0.488 & 3.85 \\
\hline 180 & 0.612 & 2.18 \\
\hline 225 & 0.725 & 2.25 \\
\hline 270 & 0.813 & 1.295 \\
\hline 315 & 0.883 & 1.79 \\
\hline 360 & 0.99 & 2.4 \\
\hline \multicolumn{2}{|r|}{ Max } & 6.165 \\
\hline \multicolumn{2}{|r|}{ Min } & 1.232 \\
\hline
\end{tabular}

From Figure 4, it can be seen that the bottom of the furrow in operation of the spading machine is uneven, the height of ridge depending on the size of the step of the working body. At a smaller step the height of ridges along the bottom of the furrow decreases. 


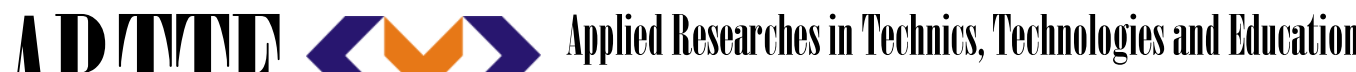 Journal of the Faculty of Technics and Technologies, Trakia University https://sites.google.com/a/trakia-uni.bg/artte/}

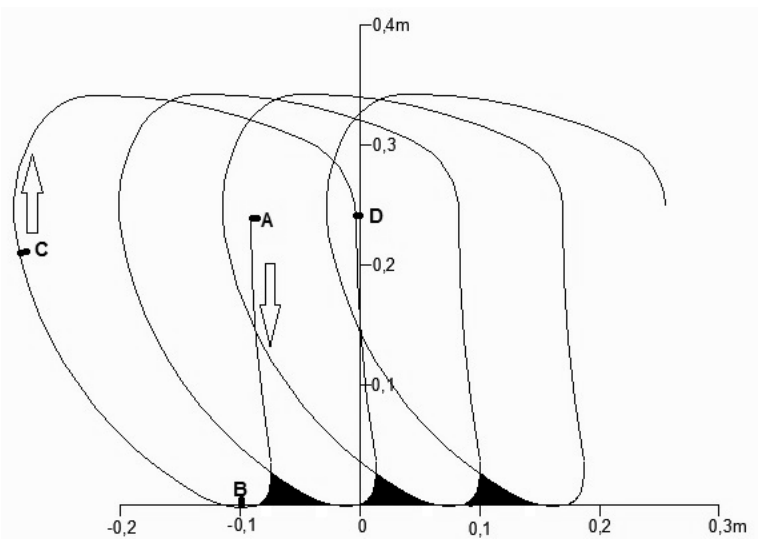

Figure 4. Trajectory of point $\mathrm{M}$ on the working body of the spading machine

Figure 5 a shows the theoretical shape of the soil chip upon first penetration of the spade into the soil, and Figure $5 \mathrm{~b}$ at each subsequent one. In practice, lowering the machine into working position is gradual with the tractor at standstill $V_{w}=0$. Thus, good soil tillage is obtained at the edges of the cultivated area as well.

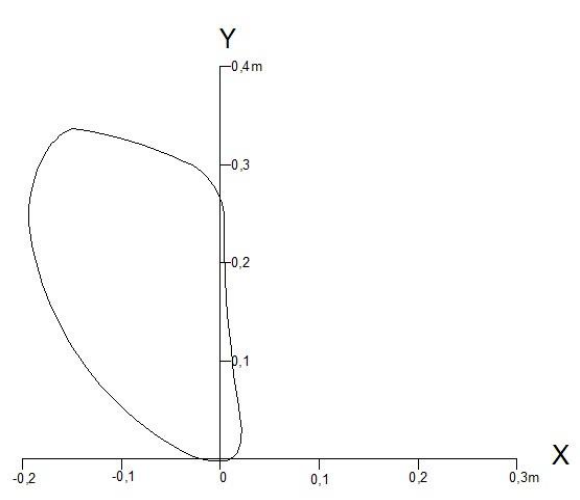

a)

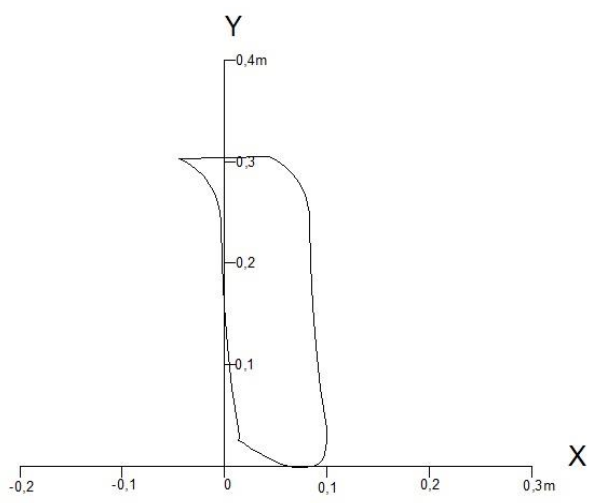

b)

Figure 5. Theoretical shape of the soil chip:

$a-$ at first insertion of the shovel into the soil; $b$ - at second and subsequent insertion of the shovel into the soil

\section{CONCLUSION}

An analysis of the kinematics of a spading machine has been made by using a specialized engineering software. It has been found out that the speed of the working body varies considerably depending on the rotation angle of the machine crankshaft. When the crankshaft rotates between $90^{\circ}$ and $135^{\circ}$, the velocity of the working body reaches its maximum value. The trajectory of the working body and the shape of the soil chip shredded by it is determined. 


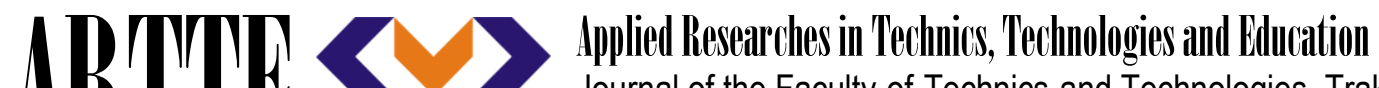 Journal of the Faculty of Technics and Technologies, Trakia University https://sites.google.com/a/trakia-uni.bg/artte/}

\section{REFERENCES}

[1] Coleman, E. (1995). The New Organic Grower. Chelsea Green, White River Jct., VT.

[2] Gasparetto E. (1966b). Nuove prove sperimentali di macchine vangatrici.

[3] Georgieva K., Tasev G. (2015). Mechanized technologies in agriculture, Sofia.

[4] Giordano D. M., Facchinetti D., Pessina D. (2015). The spading machine as an alternative to the plough for the primary tillage, Journal of Agricultural Engineering, volume XLVI: 445.

[5] Kiselev S. (1990). Towards determination of the optimum dimensions of the working body of a four-unit spading machine for greenhouses.// Agricultural machines and devices for intensive technologies: Collection of scientific papers - M.: Moscow Institute for Engineers in Agricultural Production, pp. 42-46.

[6] Kiselev S. (1995). On motivating the parameters of the spading machine for primary soil tillage in greenhouses. Autoreferate.

[7] Perepelkin A.V. (2011). Specific costs in the primary soil tillage by spading machines, Bulletin of the Federal State Educational Institution of Higher Professional Education of Moscow State Agroengineering University /MSAU/ No. 1.

[8] SAM Mechanism design by Artas Engineering Software [Online]. Available: http:// www.artas.n0l [2017-12-18].

[9] Stoyanov P. (1979). Theory of machines and mechanisms. Part 1. Gabrovo.

[10] Test report n. 03-036, Spading machine: 3012G, Testing service of functional and safety characteristics of agricultural machines, Enama, Ente Nazionale per la meccanizzazione Agricola, Roma.

[11] Vakarelski Y. et al. (1976). Agricultural machines and devices, Sofia.

[12] Vasilev S. et al. (1978). Agricultural machinery, ZEMIZDAT, Sofia. 